\title{
Relative efficiency of two zinc sources for maize (Zea mays L.) in two calcareous soils from an arid area of Iran*
}

\author{
M. Maftoun and N. Karimian
}

Shiraz University, College of Agriculture, Department of Soil Science, Shiraz, Iran

(received 22 January 1988, accepted 28 May 1989)

Summary - Effects of $2 \mathrm{Zn}$ sources ( $\mathrm{ZnEDTA}$ and $\mathrm{ZnSO}_{4}$ ) and $4 \mathrm{Zn}$ levels on the growth and $\mathrm{Zn}$ utilization by maize plants in 2 arid calcareous soils of Iran were investigated in a glasshouse study. Plants supplied with $\mathrm{Zn}$ produced more stem and leaf $\mathrm{dry}$ weights and contained more $\mathrm{Zn}$ than those grown without $\mathrm{Zn}$. Moreover, ZnEDTA was generally more effective than $\mathrm{ZnSO}_{4}$ in increasing $\mathrm{Zn}$ concentration and $\mathrm{Zn}$ uptake by stems and leaves. Results of this study indicate that the soils exhibited a highly variable capacity with regard to the growth and $\mathrm{Zn}$ accumulation. Maize seedlings grown in the Bajgah soil produced more dry matter yields and absorbed more $\mathrm{Zn}$ than those grown in the Airport soil. The more enhancing influence of $\mathrm{ZnEDTA}$ over $\mathrm{ZnSO}_{4}$ in terms of growht and $\mathrm{Zn}$ utilization by maize in arid region calcareous soils might be due to less fixation and greater transport and movement of chelated $\mathrm{Zn}$ to plant roots.

zinc - maize - fertilization - calcareous soil - Iran

Résumé - Efficacité relative de deux formes de zinc pour le maïs cultivé dans deux sols calcaires issus de régions arides d'Iran. On a étudié en serre les effets de 2 formes de zinc $\left(\mathrm{ZnSO}_{4}\right.$ et $\left.\mathrm{ZnEDTA}\right)$ et de 4 doses d'apport sur la croissance et l'absorption de Zn par du maiss cultivé sur 2 types de sols calcaires issus de régions arides d'Iran. Les plantes bénéficiant d'un apport de $\mathrm{Zn}$ ont une production supérieure de racines, de tiges et de feuilles; en outre la teneur en $\mathrm{Zn}$ est accrue. ZnEDTA s'avère plus efficace que $\mathrm{ZnSO}_{4}$, aussi bien en matière d'effet sur la croissance que sur l'absorption et l'accumulation de Zn dans les différentes parties de la plante. Les résultats de cette étude montrent par ailleurs que les 2 types de sol expérimentés sont à l'origine d'une réaction très différente du maïs à l'apport du zinc. C'est ainsi que la croissance de la plante et l'absorption du zinc sont plus importantes pour le maïs cultivé sur le sol issu du site Bajgah que sur celui issu de Airport. La supériorité de ZnEDTA sur ZnSO pour la croissance et l'utilisation de Zn par le maïs dans les 2 types de sols calcaires expérimentés peut être interprétée comme résultant d'une moindre fixation du métal par le sol et de l'amélioration de son transfert vers le système racinaire.

zinc - maïs - fertilisation - sol calcaire - Iran

\section{INTRODUCTION}

Zinc deficiency in agricultural crops is one of the most common micronutrient deficiencies (Lindsay, 1972). Since $\mathrm{Zn}$ is essential in plant nutrition, it has to be supplied to crops in some forms for optimum plant growth where $\mathrm{Zn}$ deficiency in the soil is expected. In recent years, the use of various $\mathrm{Zn}$ fertilizers to correct $\mathrm{Zn}$ deficiency has received widespread interest. In general, application of $\mathrm{Zn}$ fertilizers to most soils is relatively ineffective, since the element is readily converted to unavailable forms. The magnitude and strenght of $\mathrm{Zn}$ fixation is largely governed by soil $\mathrm{pH}$, type of soil minerals, kind and amount of anions in the soil solution and $\mathrm{Zn}$ carriers (Sharpless et al., 1969; Stanton and Burger, 1970; Shuman, 1975).

The relative effectiveness of various $\mathrm{Zn}$ sources for plant growth has been reviewed by

\footnotetext{
* Paper No. K-569-65, College of Agriculture, Shiraz University, Shiraz, Iran.
} 
several workers (Giordano and Mortvedt, 1972; Lindsay, 1972; Murphy and Walch, 1972). These reviews point out the conflicting data regarding the efficiency of various $\mathrm{Zn}$ sources for crop production. Several workers (Wallace and Romney, 1970; Prasad et al., 1976; Ragab, 1981; Dhillon and Dhillon, 1983) have reported that under glasshouse conditions, chelate forms of $\mathrm{Zn}$ were found to be more effective than inorganic forms of Zn. Brown \& Krantz (1966) noted that maize responded equally well to broadcast soil application of $\mathrm{ZnSO}_{4}$ and $\mathrm{ZnEDTA}$. When banded, $\mathrm{ZnEDTA}$ was more effective than $\mathrm{ZnSO}_{4}$. Diddowson and Watts (1977) concluded that soilapplied $\mathrm{ZnSO}_{4}$ and $\mathrm{ZnEDTA}$ produced the same maize dry matter in calcareous soils. In contrast, Shukla and Morris (1967) found that $\mathrm{ZnSO}_{4}$ and $\mathrm{Zno}$ were equally efficient or superior to chelated $\mathrm{Zn}$ in increasing the $\mathrm{Zn}$ concentration and uptake of maize in a glasshouse study. In several field experiments (Vinande et al., 1968; Boawn, 1973), ZnEDTA was more effective than $\mathrm{ZnSO}_{4}$. However, Ganiron et al. (1969) observed no advantage of $\mathrm{ZnEDTA}$ over $\mathrm{ZnSO}_{4}$ when applied as band treatment at seedling. Yet, Schnappinger et al. (1969) reported higher yield of maize in field studies from the use of inorganic sources of $\mathrm{Zn}$.

Many soils in the southern region of Iran are calcareous in nature. Most of the $\mathrm{Zn}$ disorders in plants occur in these soils (Navrot and Ravikowitch, 1969). This is believed to be caused by low solubility products of $\mathrm{Zn}$ soil complexes and carbonate (Udo et al., 1970). All indications point out that the incidence of $\mathrm{Zn}$ disorder will continue as the result of increased use of higher analysis fertilizers, inadequate $\mathrm{Zn}$ fertilization and use of high-yielding cultivars. Although some nutritional features of calcareous soils in southern Iran have been investigated, authors are not aware of any information regarding the response of maize to various $\mathrm{Zn}$ sources. Therefore, the present study was initiated to evaluate the effects of several rates of soil-applied $\mathrm{ZnSO}_{4}$ and $\mathrm{ZnEDTA}$ on the growth and $\mathrm{Zn}$ utilization of maize grown in 2 arid region calcareous soils.

\section{MATERIALS AND METHODS}

The surface $20-\mathrm{cm}$ layer of an alluvial calcareous soil was collected from 2 locations, Bajgah Agricultural Experiment Station, $15 \mathrm{~km}$ north, and Airport, $20 \mathrm{~km}$ southeast of Shiraz, Iran. The soils are classified as calcixerollic xerochrept and typic xerofluvent for the 2 locations, respectively. Some physical and chemical properties of the soils are given in Table 1.

The air-dried soils were ground to pass a $2-\mathrm{mm}$ sieve and $2000 \mathrm{~g}$ of the soil was thoroughly mixed with
Table I. Physico-chemical characteristics of the soils.

\begin{tabular}{lrr}
\hline Characteristics & Bajgah soil & Airport soil \\
\hline & & \\
Texture & Loam & Loam \\
pH & 8.20 & 7.40 \\
EC (mmhos/cm) & 0.34 & 6.90 \\
Calcium carbonate & & \\
equivalent $(\%)$ & 40.30 & 38.75 \\
Organic matter $(\%)$ & 1.63 & 1.02 \\
NaHCO ${ }_{3}$-extractable & & \\
P(mg/kg) & 10.50 & 5.50 \\
Extractable Zn(mg/kg) & & \\
$\mathrm{H}_{2} \mathrm{O}$ & 0.36 & 0.40 \\
HCl,0.1 N & 0.20 & 0.20 \\
DTPA & 0.50 & 0.50 \\
\hline
\end{tabular}

5,10 and $20 \mathrm{ZnEDTA}\left(\mathrm{Na}_{2} \mathrm{ZnEDTA}\right)$ or 10,20 and 50 $\mathrm{mg} \mathrm{Zn}$ as reagent grade $\mathrm{ZnSO}_{4}$. The control was $0 \mathrm{Zn}$ treatment. Nitrogen and $\mathrm{P}$ were added to all pots at 150 and $50 \mathrm{mg} / \mathrm{kg}$ in the form of $\left(\mathrm{NH}_{4}\right)_{2} \mathrm{SO}_{4}$ and $\mathrm{KH}_{2} \mathrm{PO}_{4}$, respectively. The experiment layout was $2 \times 2 \times 4$ factorial arrangement with 4 replications, carried out in a glasshouse with average day and night temperatures of $34^{\circ}$ and $14^{\circ} \mathrm{C}$, respectively. Six seeds of a pure line maize cultivar (DC-599) were sown in each pot and seedlings were thinned to 3 after 2 weeks. The pots were irrigated with distilled water to field capacity, as often as necessary during the course of the experiment. The plants were grown during months of May, June and for $60 \mathrm{~d}$ and harvested at the 12-leaf stage.

At harvest, tops were cut at the soil surface and separated into leaf and stem. The plant parts were then dried at $70^{\circ} \mathrm{C}$ in an oven, weighed and ground in a micromill to pass a 40-mesh sieve. One-half-gram plant samples were digested in a mixture of nitric, perchloric and sulfuric acids (5:2:1). Zinc was determined by a Carl Zeiss Atomic Absorption spectrophotometer and $\mathbf{P}$ was analyze colormetrically, using ammonium molybdate-stannous chloride method.

Growth, Zn concentration and $\mathrm{Zn}$ uptake data were regressed on $\mathrm{Zn}$ rate with respect to the $\mathrm{Zn}$ sources and the soil types.

\section{RESULTS AND DISCUSSION}

Data for each $\mathrm{Zn}$ source-soil combination were analyzed and the second order model:

$$
Y=b_{0}+b_{1} X+b_{11} X^{2}
$$

was fitted, where $Y$ is the dry weight, $Z n$ concentration or $\mathrm{Zn}$ uptake, $\mathrm{X}$ is $\mathrm{Zn}$ rate, $\mathrm{b}_{0}$ is the intercept and $b_{1}$ and $b_{11}$ are computed regression coefficients indicating linear or quadratic effect, respectively. Equations were estimated sequentially, beginning with a linear model. Quadratic term was added only if its inclusion significantly reduced the residual mean squares. The estimated regression equations are 


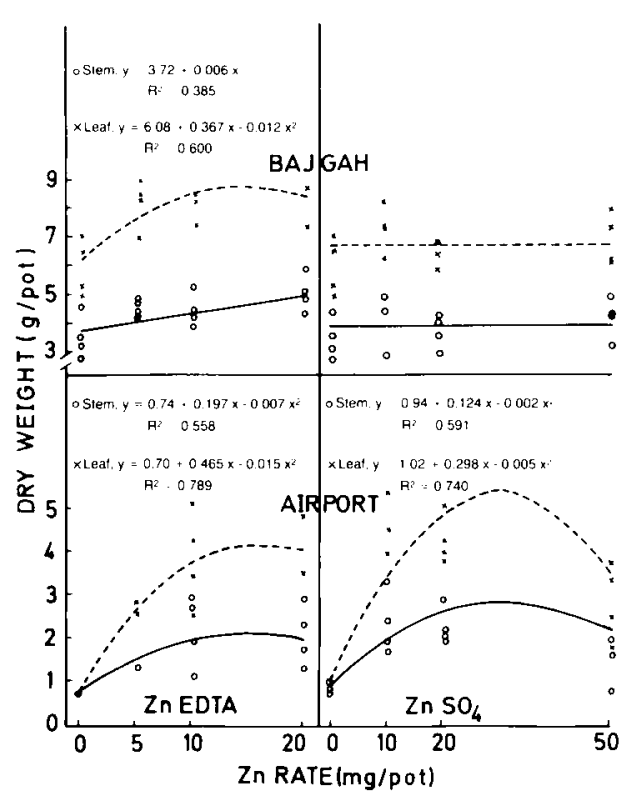

Fig. 1. Stem $(0-0)$ and leaf $(X-.-X)$ dry weights of corn as affected by the rate and form of $Z n$.

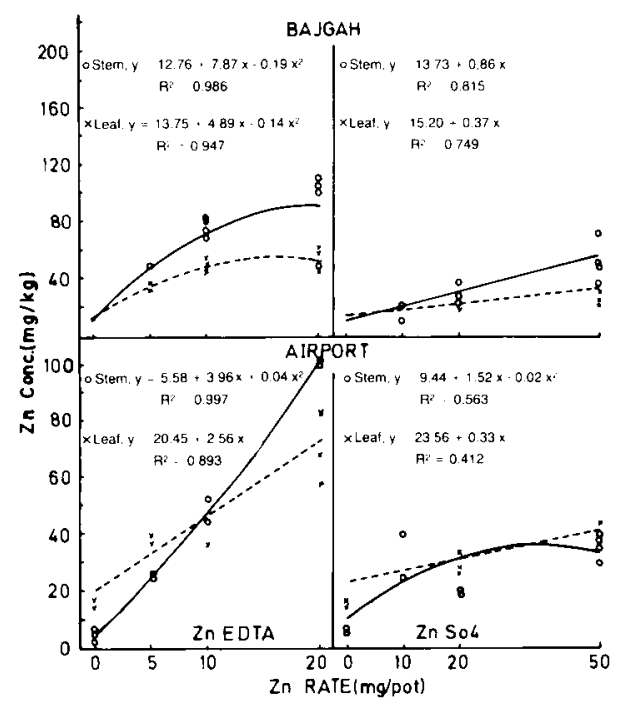

Fig. 2. Zinc concentration of stem $(0-0)$ and leaf $(X--X)$ of corn as affected by the rate and form of $\mathrm{Zn}$.

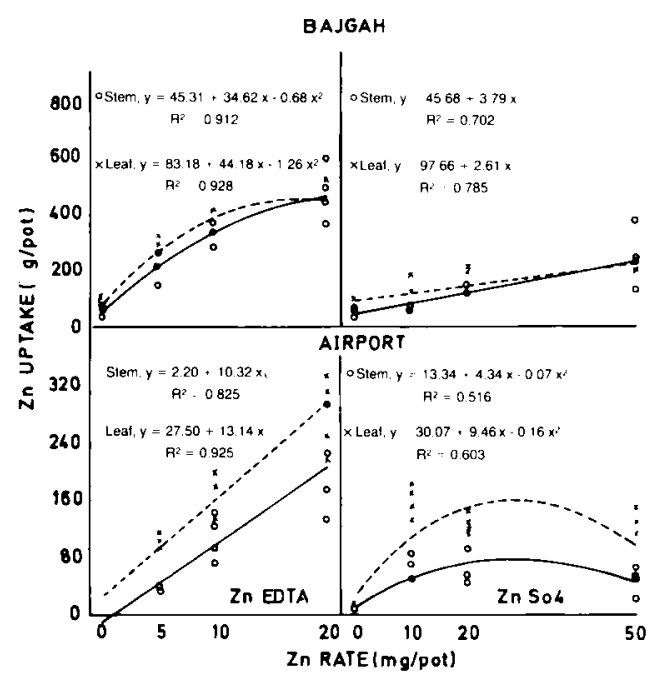

Fig. 3. Zinc uptake by stem $(0-0)$ and leaf $(X-\cdots)$ of corn as affected by the rate and form of $\mathrm{Zn}$. graphically shown in Figures 1,2 and 3. Also included in Figures 1,2 and 3 are coefficient of determinations which provide a subjective measure of goodness of fit.

In general, the dry matter yield of maize grown in the Bajgah soil was significantly higher than that grown in the Airport soil (Fig. 1). The lower dry matter production in the Airport soil was probably due to the relatively high soluble salts of this soil $(\text { Table } 1)^{*}$. Similar results have been reported for other crop species (Maas et al., 1972; Kashirad et al., 1978).

Zinc addition generally increased stem and leaf dry weights in both soils (Fig. 1). The stimulation of stem and leaf growth exhibited by $\mathrm{Zn}$ fertilization is in agreement with previous reports by others (Wallace and Romney, 1970; Ghaly et al., 1979; Prasad and Sinha, 1981; Dhillon and Dhillon, 1983; Singh et al., 1983). Furthermore, for maize grown in the Bajgah soil, the relationship between applied $\mathrm{Zn}$ as ZnEDTA and stem dry weight was linear and became curvilinear for leaf dry weight (Fig. 1).

With respect to the Airport soil, there was curvilinear relationship between $\mathrm{Zn}$ level and leaf and stem dry weights under $\mathrm{ZnEDTA}$ and $\mathrm{ZnSO}_{4}$ nutritional regimes (Fig. 1). Addition of $\mathrm{Zn}$ up to $10 \mathrm{mg} /$ pot as ZnEDTA resulted in more leaf dry weight than that of $\mathrm{ZnSO}_{4}$. However, with $20 \mathrm{mg}$ $\mathrm{Zn} /$ pot, plant supplied with $\mathrm{ZnSO}_{4}$ produced more leaf growth than those provided with ZnEDTA. In the present study application of $\mathrm{Zn}$ to the Airport soil as $\mathrm{ZnSO}_{4}$ generally was more stimulative to stem growth than that of ZnEDTA (Fig. 1). Moreover, stem and leaf dry weights were somewhat suppressed with the highest $\mathrm{ZnEDTA}$ and $\mathrm{ZnSO}_{4}$ application rates. This could be possibly due to induced $\mathrm{P}, \mathrm{Mn}, \mathrm{Fe}$ or $\mathrm{Cu}$ deficiencies.

The stem and leaf growth stimulation by ZnEDTA was more pronounced in the Airport soil than in the Bajgah soil. For instance, stem and leaf dry weights of maize grown in the Bajgah soil were increased by 36 and $40 \%$, respectively, when $\mathrm{Zn}$ level was increased from 0 to 20 $\mathrm{mg} /$ pot, while for the Airport soil, those increases were 178 and $486 \%$, respectively. Ravikovitch and Navrot (1976) reported that addition of ZnEDTA increased the tomato (Lycopersicon esculentum Mill.) yield by 18 and $58 \%$ at the soil salinity levels of 9 and $11 \mathrm{mmhos} / \mathrm{cm}$, respectively.

The influences of added $\mathrm{Zn}$ on $\mathrm{Zn}$ concentration in stems and leaves of maize

* The dominant salt in the Airport soil is believed to be sodium chloride. Excess sodium chloride has been shown to be detrimental to the growth of many plants including maize. 
plants in both soils are shown in Figure 2. Zinc fertilization significantly increased the $\mathrm{Zn}$ concentration in various plant parts. In the Bajgah soil $Z n$ concentration in stems and leaves continued to increase with an increase in $\mathrm{Zn}$ level as $\mathrm{ZnSO}_{4}$, whereas the relationships became curvilinear for ZnEDTA-treated plants. On the other hand, the concentration of $\mathrm{Zn}$ in maize leaves tended to increase linearly with the addition of $\mathrm{Zn}$ to the Airport soil as $\mathrm{ZnEDTA}$ and/or $\mathrm{ZnSO}_{4}$.

In the regression equation $Y=b_{0}+b_{1} X b_{11} X^{2}$, $b_{1}$ is actually the amount of response obtained per unit of applied $\mathrm{Zn}$.

It therefore may be used as a criterion to compare the effectiveness of different sources and to evaluate their performance in the 2 soils. The larger the $b_{1}$ value, the more effective the source under consideration. The $b_{11}$ does not generally alter the discussion here due to its comparatively small value. Examination of $b_{1}$ values given in Figure 2 indicates that ZnEDTA gave a significantly higher $\mathrm{Zn}$ concentration than $\mathrm{ZnSO}_{4}$. The more enhancing influence of $\mathrm{ZnEDTA}$ in terms of $\mathrm{Zn}$ concentration over $\mathrm{ZnSO}_{4}$ has been reported by others (Boawn et al., 1957; Wallace and Romney, 1970; Wallace, 1971; Dhillon and Dhillon, 1983). Ganiron et al. (1969) noted that in growth chamber solution culture studies, ZnEDTA produced slightly higher concentration of $\mathrm{Zn}$ in maize tissue than did $\mathrm{ZnSO}_{4}$, but only at a concentration of $2.0 \mu \mathrm{M} \mathrm{Zn}$. At $0.5 \mu \mathrm{M} Z n$ concentration, there was little if any difference between the 2 forms. The higher $\mathrm{Zn}$ concentration due to ZnEDTA application may be attributed to higher mobility and less fixation of $\mathrm{Zn}$ from $\mathrm{ZnEDTA}$ than from $\mathrm{ZnSO}_{4}$ (Kumar and
Singh, 1979). Lahav and Hochberg (1975) found that ZnEDTA was not fixed in soil and was quite mobile. Several workers (Elgawhary et al., 1970; Prasad et al., 1976; Halvorson \& Lindsay, 1977; Nand and Verloo, 1983) have reported that $\mathrm{Zn}$ chelation increases the transport and movement of $\mathrm{Zn}$ to plant roots.

Differences in $\mathrm{Zn}$ uptake as a function of $\mathrm{Zn}$ addition to both soils are shown in Figure 3 . The uptake of $\mathrm{Zn}$ generally increased with increasing $\mathrm{Zn}$ rates and was mainly due to an increase in either dry matter yield or $\mathrm{Zn}$ concentration in various plant parts. Moreover, maize seedlings supplied with $\mathrm{ZnEDTA}$ accumulated more $\mathrm{Zn}$ in stem and leaf than those provided with $\mathrm{ZnSO}_{4}$. These findings are in agreement with those of Wallace and Romney (1970) and Rhem et al. (1980). The results of this experiment indicate that the soils tested exhibit a highly variable capacity to accumulate $\mathrm{Zn}$ due to $\mathrm{Zn}$ supplement. Maize plants grown in the Bajgah soil contained more $\mathrm{Zn}$ than those grown in the Airport soil.

Phosphorus $\mathrm{Zn}$ ratio could be used as an index of the $\mathrm{Zn}$ status of the plant. In the present experiment, $\mathrm{Zn}$ application decreased $\mathrm{P} / \mathrm{Zn}$ ratio (Table II). ZnEDTA proved to be more effective in decreasing $\mathrm{P} / \mathrm{Zn}$ ratios in stem and leaf than $\mathrm{ZnSO}_{4}$. Suppression of $\mathrm{P} / \mathrm{Zn}$ ratio associated with the $\mathrm{Zn}$ application as either source was greater in the Airport soil than in the Bajgah soil.

\section{CONCLUSION}

From the foregoing discussion, it is concluded that fertilization with $\mathrm{Zn}$ has to be taken into account when considering factors that might

Table II. Effects of rate and source of $\mathrm{Zn}$ on $\mathrm{P} / \mathrm{Zn}$ ratio in maize.

\begin{tabular}{|c|c|c|c|c|}
\hline \multirow{3}{*}{$\begin{array}{l}\text { Zn applied } \\
\text { (mg/pot) }\end{array}$} & \multicolumn{4}{|c|}{$P / Z n$ ratio } \\
\hline & \multicolumn{2}{|c|}{ Stem } & \multicolumn{2}{|c|}{ Leaf } \\
\hline & Bajgah soil & Airport soil & Bajgah soil & Airport soil \\
\hline \multicolumn{5}{|c|}{ ZnEDTA } \\
\hline 0 & 191 & 456 & 149 & 144 \\
\hline 5 & 54 & 87 & 56 & 47 \\
\hline 10 & 30 & 43 & 43 & 34 \\
\hline 20 & 23 & 23 & 34 & 25 \\
\hline \multicolumn{5}{|c|}{$\mathrm{ZnSO}_{4}$} \\
\hline 0 & 191 & 456 & 149 & 144 \\
\hline 10 & 119 & 66 & 94 & 40 \\
\hline 20 & 63 & 87 & 69 & 61 \\
\hline 50 & 35 & 63 & 49 & 44 \\
\hline
\end{tabular}


enhance maize growth in saline soils. Furthermore, ZnEDTA proved to be a more efficient source of $\mathrm{Zn}$ for maize in arid region calcareous soils than $\mathrm{ZnSO}_{4}$. Better response of maize to ZnEDTA might be attributed to less fixation and greater transport of $\mathrm{Zn}$ to plant roots. A possible alternative procedure is to plant more $\mathrm{Zn}$ efficient crop species or cultivars where use of $\mathrm{Zn}$ chelates is not economically justified.

\section{RÉFÉRENCES}

Boawn L.C. (1973) Comparison of zinc sulfate and zinc EDTA as zinc fertilizer sources. Soil Sci. Soc. Am. Proc. 37, 111-115

Boawn L.C., Viets F.G.J \& Crawford C.L. (1957) Plant utilization of zinc from various types of zinc compounds and fertilizer materials. Soil Sci. 83, 219227

Brown A.L. \& Krantz B.A. (1966) Source and placement of zinc and phosphorus for corn (Zea mays L.). Soil Sci. Soc. Am. Proc. 30, 86-89

Dhillon K.S. \& Dhillon S.K. (1983) Relative efficiency of different chelates in the supply of applied zinc to maize and wheat. J. Nucl. Agric. Biol. 12, 93-96

Diddowson J.P. \& Watts H.M. (1977) Zinc deficiency in the shallow soils af Niue. III. Response of sweet corn to sources of zinc. New Zealand J. Exp. Agric. 5, 241248

Elgawhary S.M., Lindsay W.L. \& Kemper W.D. (1970) Effect of EDTA on the self-diffusion of zinc in aqueous solution and soil. Soil Sci. Soc. Am. Proc. 34, 66-70

Ganiron R.B., Adrian D.C., Paulsen G.M. \& Murphy L.S. (1969) Effects of phosphorus carriers and zinc source on phosphorus-zinc interaction in corn. Soil Sci. Soc. Am. Proc. 33, 306-309

Ghaly S., Eskander A., Azmy M. \& Mawardi A. (1979) Response of corn plant to $\mathrm{N}$ and $\mathrm{Zn}$ application on calcareous soils. Agric. Res. Rev. 57, 167-173

Giordano P.M. \& Mortoedt J.J. (1972) Agronomic effectiveness of micronutrients in macronutrient fertilizers. In: Micronutrients in Agriculture (J.J. Mortvedt et al. eds), Soil Sci Soc. Am. Inc., Madison, WI, pp. 505-523

Halvorson A.D. \& Lindsay W.L. (1977) The critical zinc concentration for corn and the non-absorption of chelated zinc. Soil Sci. Soc. Am. J. 41, 531-534

Kashirad A., Bassiri A. \& Kheradnam M. (1978) Responses of cowpeas to application of $\mathrm{P}$ and $\mathrm{Fe}$ in calcareous soils. Agron. J. 70, 67-70

Kumar V. \& Singh M. (1979) Sulfur and zinc relationship on uptake and utilization of zinc in soybean. Soil Sci., 128, 343-347

Lahav N. \& Hochberg M. (1975) Fixation of iron and zinc applied as chelates into soil solution during leaching. Soil Sci. Soc. Am. Proc. 39, 1213-1215

Lindsay W.L. (1972) Zinc in soils and plant nutrition. Adv. Agron. 24, 147-186

Maas E.V., Ogata G.M. \& Garber M.J. (1972) Influence of salinity on $\mathrm{Fe}, \mathrm{Mn}$, and $\mathrm{Zn}$ uptake by plants. Agron. J. $64,793-795$
Murphy L.S. \& Walch L.M. (1972) Correction of micronutrient deficiencies with fertilizers. In: Micronutrients in Agriculture (J.J. Mortvedt et al., eds.), Soil Sci. Soc. Am. Inc., Madison, WI, pp. 347-381

Nand R. \& Verloo M. (1983) Diffusion of zinc in heavy clay soil as influenced by application of natural complexing agents and their $\mathrm{Zn}$-complexes. Agrochimica 27, 185-191

Navrot J. \& Ravikovitch S. (1969) Zinc availability in calcareous soils: II. The level and properties of calcium in soils and its influence on zinc availability. Soil. Sci. 108, 30-37

Prasad B. \& Sinha M.K. (1981) The relative efficiency of zinc carriers on growth and zinc nutrition of corn. Plant Soil 62, 45-52

Prasad B., Sinha M.K. \& Randhawa N.S. (1976) Effect of mobile chelating agents on the diffusion of zinc in soils. Soil Sci. 122, 260-266

Ragab S.M. (1981) Response of barley to two forms of nitrogen and two sources of zinc. Agrochimica 25, 5225-534

Ravikovitch S. \& Navrot J. (1976) The effect of manganese and zinc on plants in saline soil. Soil Sci. 101, 25-31

Rhem G.W., Wiese R.A. \& Hergert G.W. (1980) Response of corn to zinc source and rate of zinc bandapplied with either orthophosphate or polyphosphate. Soil Sci. 129, 36-44

Schnappinger M.G., Martens D.C. \& Hawkins G.W. (1969) Response of corn to $\mathrm{Zn}$-EDTA and $\mathrm{ZnSO}_{4}$ in field investigations. Agron. J. 61, 834-836

Sharpless R.G., Wallihan E.F. \& Peterson F.F. (1969) Retention of zinc by some arid-zone soil materials treated with zinc sulfate. Soil. Sci. Soc. Am. Proc. 33, 901-904

Shukla U.C. \& Morris H.D. (1967) Relative efficiency of several zinc sources for corn (Zea mays L.). Agron. J. $59,200-202$

Shuman L.M. (1975) The effect of soil properties on zinc adsorption by soils. Soil Sci. Soc. Am. Proc. 39, 454-458

Singh B.P., Sakal R. \& Singh A.P. (1983) Relative performance of soil-applied zinc sulfate and other zinc carriers used as coating for seeds of maize and rice. Indian J. Agric. Res. 53, 918-921

Stanton D.A. \& Burger R.D.U.T. (1970) Studies on zinc in selected Orange Free State soils. Factors affecting the availability of zinc. Agrochemophysica 2, 33-40

Udo E.J., Bohn H.L. \& Tucker T.C. (1970) Zinc adsorption by calcareous soil. Soil Sci. Soc. Am. Proc. 34, 405-407

Vinande R., Kenzel B., Davis J., Doll E. \& Meiton J. (1968) Field and laboratory studies with zinc and iron fertilization of pea, beans, corn, and potatoes in 1967. Mich. Agric. Exp. Stn. Quart. Bull. 50, 625-636

Wallace A. (1971) Effects of sources of zinc on zinc uptake by corn plants grown in Dinuba fine sandy loam soil. In: Regulation of the Micronutrient Status of Plants by Chelating Agent and Other Factors (A. Wallace \& E.M. Romney, eds.) A. Wallace, Los Angeles, CA, pp. 124-125

Wallace A. \& Romney E.M. (1970) The effect of $\mathrm{Zn}$ sources on micronutrient contents of Golden Cross Bantam corn. Soil Sci. 109, 66-67 